Jurnal Pendidikan Kimia

Vol. 12 | No. $3 \mid 124$ - 135| December | 2020 ISSN: 2085-3653| e-ISSN: 2549-3116

https://jurnal.unimed.ac.id/2012/index.php/jpk

https://jurnal.unimed.ac.id

\title{
Effect of cooperative learning model type of group investigation and adversity quotient of students on mastery of chemical concepts on salt hydrolysis material
}

\author{
Havizhah $^{1 *}$, Muhaimin $^{2}$ and Damris Muhammad ${ }^{2}$ \\ ${ }^{1}$ Chemisrty Education Study Program, Postgraduate, Jambi University, Jambi 36361, Indonesia \\ ${ }^{2}$ Departemen of Chemisrty Education, Jambi University, Jambi 36361, Indonesia \\ *Corresponding author: Hz, havizhah15@gmail.com
}

DOI: 10.24114/jpkim.v12i3.21161

Article history:

Received: 29 September 2020

Revised: 12 November 2020

Accepted: 13 November 2020

Abstract: This study aims to see the effect of the cooperative learning model type of group investigation and adversity quotient of students on the mastery of chemical concepts on salt hydrolysis. This research is a quasi-experimental research with a control group posttest only design using a $2 \times 3$ factorial design. The research was conducted in class IX MIA SMA N 10 Batanghari with two classes. Sampling was done by total sampling. Data collection techniques are questionnaires, tests and documentation. The test instrument was used to determine the value of mastery of chemical concepts on salt hydrolysis. Meanwhile, the questionnaire instrument was used to determine the level of adversity quotient of students. Data processing used two-way ANOVA. The results showed that the cooperative learning model group Investigation type and the adversitiy quotient of the climber type students had high mastery of chemical concepts, but there was no interaction between the group investigation type learning model and the adversity quotient on the mastery of chemical concepts on salt hydrolysis due to the learning model and adversity quotient influence on mastery of chemical concepts independently. Based on the results of the study, it can be concluded: (1) there is an effect of the group investigation type cooperative learning model on the mastery of chemical concepts (2) there is an effect of students adversity quotient on chemical concept mastery (3) there is no interaction between the cooperative learning model group investigation type with students' adversity quotient on mastery of chemical concepts in salt hydrolysis.

Keywords: Cooperative learning model type of group investigation ( $\mathrm{Gl}$ ), Adversity quotient (AQ), Mastery of chemical concepts, Salt hydrolysis

\section{Introduction}

Chemistry learning is an inseparable part of learning science. Inquiry and discovery make learning more meaningful for students because students are involved in concept discovery. One of the problems faced by the world of education is the 
problem of a weak learning process. Children are less encouraged to work actively in the learning process (Anitah, 2007). The learning process in the classroom is often directed at the student's ability to memorize information, the student's brain is forced to remember and accumulate various information without being required to understand the memorized information to relate it to everyday life. This causes a lack of mastery of student concepts and student learning outcomes.

The low learning outcomes (concept understanding) of students' chemistry is due to the use of strategies, methods and models that are less varied or teachers are often the center of learning (teacher centered). Then the learning methods that are often used only use lectures, exercises and assignments which cause students to become bored and not interested in learning chemistry. The students' low mastery of concepts results in low learning outcomes. This is supported by the opinion (Rokhayati, 2010) that learning concepts is the main result of education. Concepts are the building blocks of thinking and also the basis for higher mental processes for formulating principles and generalizations.

The learning model in accordance with the above problems is the Group Investigation (GI) learning model. Previous research by (Ekayanti et al. 2011), which shows that with the $\mathrm{Gl}$ model increases student participation in the teaching and learning process, the $\mathrm{Gl}$ learning model requires teachers to prepare problems for a group of students who have different abilities. Students who have less ability tend to seek help from peers to understand the material.

Some of the advantages of the Group Investigation (GI) type of cooperative learning model include: it is suitable for integrated study projects, there is an investigation phase, has a lot of compatibility with science learning, students can understand scientific investigations and facilitate understanding concepts more deeply, and students directed to find a concept or principle together (Hartono, 2006). In this learning model students are given freedom and are facilitated to find concepts or principles together so that students' interest in learning in chemistry lessons increases, because it gives freedom to discover concepts. In accordance with Jensen's opinion in (Andi and Handayani, 2015) physical movements during the learning process such as investigating, observing can improve circulation so that the nerves can get a lot of oxygen and nutrients; can stimulate the production of dopamine, a neotransmitter that improves mood in learning. Based on the advantages of the Group Investigation (GI) type of cooperative learning model, the researcher believes that this model is suitable when applied to chemical materials, especially salt hydroolysis.

However, on the other hand, the students' low learning outcomes or mastery of chemical concepts, especially in the matter of salt hydrolysis, is also caused by the low fighting power of students in solving questions because when given questions, students immediately give up while students are still reading or even just looking at the numbers, even though students have not tried to solve it. 
Based on several research results, it shows that students with high Adversity Quotient (AQ) will achieve good learning outcomes. As well as the findings expressed by Fauziah et al. (2020) that $A Q$ is a factor that affects student academic achievement. Another study by (Lubis, 2017) found that $A Q$ has a positive relationship with students' physics learning outcomes. Another study by (Fauziah et al. 2020) has revealed the effect of $A Q$ on mathematics learning achievement of junior high school students.

In this study, it will be seen how the Adversity Quotient (AQ) is owned by each student. With the Adversity Quotient (AQ) that students have, the teacher will know how the businesses they have, and to what extent students are able to overcome the difficulties they are experiencing. The teacher will find out whether students easily give up in overcoming difficulties or vice versa students will try to overcome these difficulties.

\section{Methods}

This research was conducted at SMAN 10 Batanghari class XI MIA about salt hydrolysis. This research is a quasi experimental research with $2 \times 3$ factorial research design. The research design is shown in Table 1.

The population in this study were students of class XI MIA at SMA N 10 Batanghari in the 2018/2019 academic year. The sampling technique was carried out by total sampling and obtained two sample classes, namely class XI MIA 1 as an experimental class with a total of 33 students and class XI MIA 2 as a control class with a total of 34 students.

\section{Table 1}

Factorial design $2 \times 3$

\begin{tabular}{c|c|c}
\hline Learning model $(\mathrm{X})$ & $\begin{array}{c}\text { Eksperiment } \\
\text { Group Investigationt } \\
\left(\mathrm{X}_{1}\right)\end{array}$ & $\begin{array}{c}\text { Control } \\
\text { Direct Instruction } \\
\left(\mathrm{X}_{2}\right)\end{array}$ \\
\hline AQ Climber Type $\left(\mathrm{Y}_{1}\right)$ & $\begin{array}{c}\left(\mathrm{X}_{1} \mathrm{Y}_{1}\right) \\
\text { (mastery of chemical } \\
\text { concepts) }\end{array}$ & $\begin{array}{c}\left(\mathrm{X}_{2} \mathrm{Y}_{1}\right) \\
\text { (mastery of chemical } \\
\text { concepts) }\end{array}$ \\
\hline AQ Camper Type $\left(\mathrm{Y}_{2}\right)$ & $\begin{array}{c}\left(\mathrm{X}_{1} \mathrm{Y}_{2}\right) \\
\text { (mastery of chemical } \\
\text { concepts) }\end{array}$ & $\begin{array}{c}\left(\mathrm{X}_{2} \mathrm{Y}_{2}\right) \\
\text { (mastery of chemical } \\
\text { concepts) }\end{array}$ \\
\hline AQ Quitter Type $\left(\mathrm{Y}_{3}\right)$ & $\begin{array}{c}\left(\mathrm{X}_{1} \mathrm{Y}_{3}\right) \\
\left(\mathrm{X}_{2} \mathrm{Y}_{3}\right)\end{array}$ \\
& $\begin{array}{c}\text { (mastery of chemical } \\
\text { concepts) }\end{array}$ & $\begin{array}{c}\text { (mastery of chemical } \\
\text { concepts) }\end{array}$ \\
\hline
\end{tabular}

Data collection techniques are questionnaires, tests and documentation. The test instrument was used to determine the value of mastery of chemical concepts on salt 
hydrolysis. Meanwhile, the questionnaire instrument was used to determine the level of adversity quotient (AQ) of students.

The data analysis technique used is a descriptive, prerequisite test and hypothesis testing. The prerequisite test used was the normality test or the KolmogorovSmirnov test and the homogeneity test used the Levene test. To test the hypothesis, the researcher used data analysis techniques with two-way analysis of variance (ANOVA) with a significant level of interaction $\alpha=0.05$ or $5 \%$.

\section{Results and Discussion}

The data obtained in this study were students' Adversity Quotient (AQ) data and data on mastery of chemical concepts. Adversity Quotient students are obtained from the $A Q$ questionnaire given to students before learning. Meanwhile, mastery of chemical concepts is obtained by using posttests on salt hydrolysis.

Data Adversity Quotient students are taken in the experimental group, namely the class that applies the Group Investigation learning model and the control group, namely the class that applies the Direct Instruction learning model. Data were taken at the beginning of learning to determine the level of adversity quotient of students. On the student's Adversity Quotient questionnaire sheet there are 30 events that contain difficulties or obstacles (except for those that are positive) then each event is followed by 2 statements. The questionnaire used is the result of an adaptation from Stoltz (2000) based on CO2RE dimensions which are then modified according to research needs. There are three levels or categories of AQ, namely: climber, camper, and quitter. The following is the data from the student Adversity Quotient questionnaire in Fig 1.

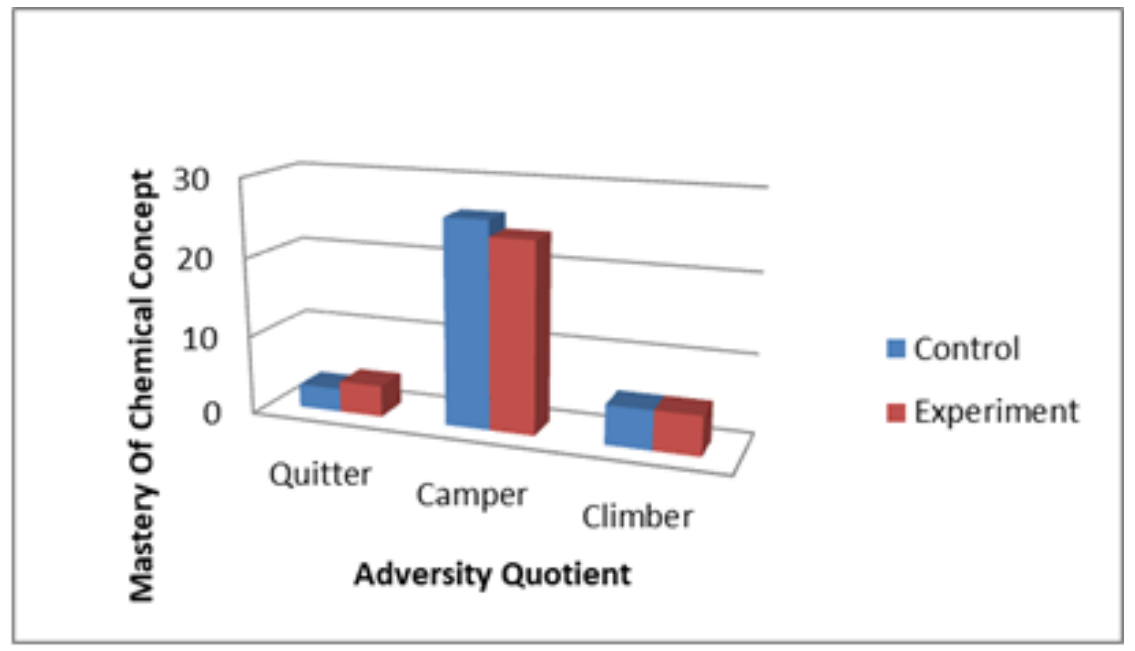

Fig 1. Distribution of the Number of Students based on the Adversity Quotient (AQ) Questionnaire

Based on Figure 1, it is known that the number of students who have AQ at the quitter level is in the control group 3 students and the experimental group 4 
students. The number of students who have $A Q$ at camper level in the control group is 26 students and the experimental group is 24 students. The number of students who have a climber level AQ in the control group is 5 students and the experimental group is 5 students

The highest number of students in the control group and the experimental group was at the camper level adversity quotient with a percentage of $76.47 \%$ in the control class and $69.69 \%$ in the experimental group. Meanwhile, the percentage for the quitter level adversity quotient in the control group was $8.82 \%$ and in the experimental group was $12.12 \%$. Furthermore, the percentage for the climber level adversity quotient in the control group was $14.70 \%$ and in the experimental group was $18.18 \%$

The data on students' mastery of chemical concepts were obtained from the results of tests carried out after being given treatment in the control and experimental classes. The data description of the students' mastery of chemical concepts is presented in Table 2.

Table 2

Data on the value of mastery of chemical concepts on salt hydrolysis

\begin{tabular}{l|c|c|c|c|c}
\hline \multicolumn{1}{c|}{ Class } & $\mathrm{N}$ & $\begin{array}{c}\text { Lowest } \\
\text { Value }\end{array}$ & $\begin{array}{c}\text { Highest } \\
\text { Value }\end{array}$ & Mean & Std.Deviasi \\
\hline Control & 34 & 54 & 88 & 72.71 & 8.59 \\
\hline Experiment & 33 & 68 & 95 & 79.97 & 6.78 \\
\hline
\end{tabular}

Based on table 2, the results of the data description in the experimental class and control class show that the experimental class that applied the group investigation (GI) model had a better mean score than the control class that applied the direct instruction (DI) learning model.

Before testing the hypothesis, a prerequisite test is carried out by testing the normality and homogeneity of the data group. This pre-test was carried out using SPSS version 16. Data from the normality test and homogeneity test are summarized in Table 3 and Table 4.

Table 3.

Data normality test results of mastery of chemical concepts on salt hydrolysis

\begin{tabular}{|c|c|c|c|c|}
\hline & \multirow[b]{2}{*}{ Class } & \multicolumn{3}{|c|}{ Kolmogorov-Smirnov ${ }^{a}$} \\
\hline & & Statistic & Df & Sig. \\
\hline \multirow{2}{*}{$\begin{array}{l}\text { mastery of chemical } \\
\text { concepts }\end{array}$} & Control & .136 & 34 & .115 \\
\hline & Experiment & .113 & 33 & .200 \\
\hline
\end{tabular}

In Table 3, the analysis results show that the significant value of the KolmogorovSmirnov calculation is higher than 0.05. This means that the results of the creative thinking ability of the two samples are normally distributed. 
Table 4

Homogeneity test data results the value of mastery of chemical concepts

\begin{tabular}{c|c|c|c}
\hline Levene Statistic & $\mathrm{df1}$ & $\mathrm{df} 2$ & Sig. \\
\hline 2.240 & 1 & 65 & .139 \\
\hline
\end{tabular}

Based on the results of the homogeneity test in Table 4, it shows that the significance value of the variance is greater than 0.05 . This means that the results of students' creative thinking abilities from the two samples are stated to be homogeneous.

Furthermore, hypothesis testing was carried out using two-way analysis of variance (ANOVA) techniques with interactions at the significance level of $\alpha=0.05$ or 5\%. Using SPSS version 16 after previously measuring the post-test results of mastery of chemical concepts from students. The data description of the results of the mastery of chemical concepts with the student adversity quotient category is presented in Table 5.

Table 5

Description of the results of mastery of chemical concepts based on the adversity quotient

\begin{tabular}{l|l|c|c|c}
\hline \multirow{2}{*}{ Class } & Adversity & & & \\
\hline Quntrol & Quotient & Mean & Std. Deviation & $\mathrm{N}$ \\
\hline & Camper & 62.67 & 7.506 & 3 \\
& Climber & 77.62 & 7.255 & 26 \\
& Total & 72.71 & 12.095 & 5 \\
\hline \multirow{2}{*}{ Experiment } & Quitter & 69.50 & 1.000 & 4 \\
& Camper & 79.38 & 3.910 & 24 \\
& Climber & 91.20 & 3.114 & 5 \\
& Total & 79.97 & 6.780 & 33 \\
\hline
\end{tabular}

Based on Table 5 and Fig 2 above, it can be seen that there is a difference in the average score of the students' chemistry concept mastery test in the two research groups. In the control class, namely a group of students who carry out learning with the Direct Instruction learning model with the Adversity Quotient type quitter known to be an average of 62.67. the same group of students but with the camper type Adversity Quotient it was known that the average was 72.92. And still with the same group of students with the climber type Adversity Quotient, it is known that the average is 77.60 . 


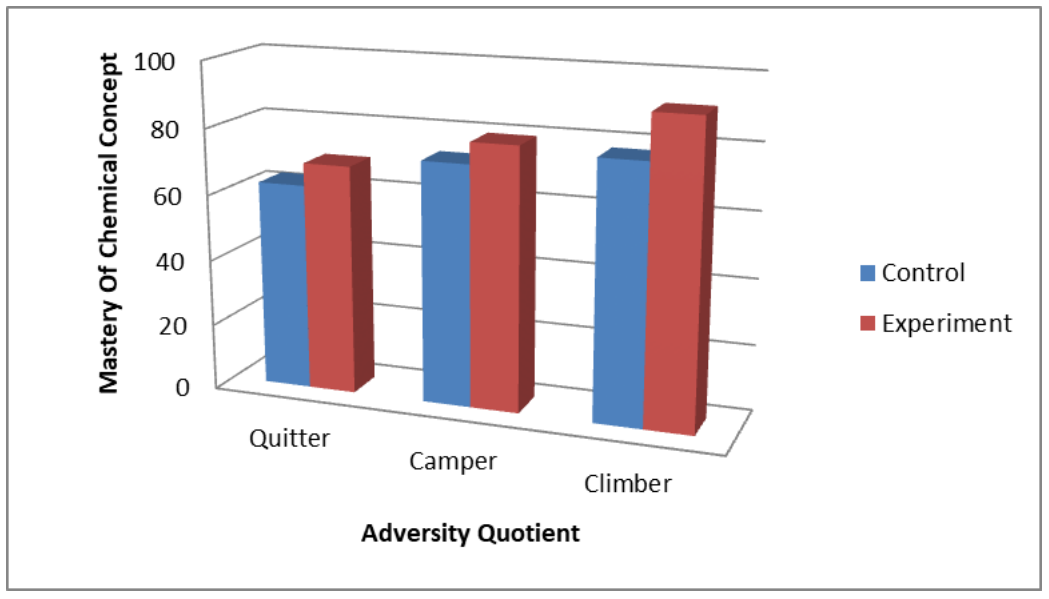

Fig 2. Graph of the Average Value of Mastery of Chemical Concepts

In the experimental class, the group learning of students using the $\mathrm{Gl}$ cooperative learning model, the Adversity Quotient type quitter, is known to have an average of 69.50. Then the camper type Adversity Quotient is known to have an average of 79.38 while the Climber type Adversity Quotient is known to have an average of 91.20.

Furthermore, the results of hypothesis testing were carried out using two-way analysis of variance (ANOVA) techniques with interaction. The data calculation from the results of hypothesis testing is presented in Table 6.

Table 6

Two-way ANOVA test data

\begin{tabular}{l|c|c|c|c|c|c}
\hline Source & $\begin{array}{c}\text { Type III Sum of } \\
\text { Squares }\end{array}$ & $\mathrm{df}$ & Mean Square & $\mathrm{F}$ & Sig. & $\begin{array}{c}\text { Partial Eta } \\
\text { Squared }\end{array}$ \\
\hline Corrected Model & $2384.474^{\mathrm{a}}$ & 5 & 476.895 & 12.085 & .000 & .498 \\
Intercept & 193188.865 & 1 & 193188.865 & $4.896 \mathrm{E} 3$ & .000 & .988 \\
Model & 679.683 & 1 & 679.683 & 17.224 & .000 & .220 \\
AQ & 1372.814 & 2 & 686.407 & 17.394 & .000 & .363 \\
Model * AQ & 107.433 & 2 & 53.716 & 1.361 & .264 & .043 \\
Error & 2407.138 & 61 & 39.461 & & & \\
Total & 394677.000 & 67 & & & & \\
Corrected Total & 4791.612 & 66 & & & & \\
\hline
\end{tabular}

Based on the data in Table 6 above, the results of the first hypothesis test, the effect of the group investigation learning model on mastery of chemical concepts, show that the $F_{\text {count }}$ value is 17.224 with a significance value of 0.000 . Because the significance $<0.05$, Ho is rejected and $\mathrm{H} 1$ is accepted. This means that there is an 
effect of using the group investigation $(\mathrm{Gl})$ learning model on the mastery of chemical concepts in the salt hydrolysis material.

Learning outcomes in the experimental class can increase if the $\mathrm{Gl}$ type of cooperative learning model is applied. because according to Mitchell's (2008) statement that the $\mathrm{Gl}$ type of cooperative learning model still offers students the opportunity to have their own learning and shows the knowledge and understanding of students so that the material being studied can achieve higher learning outcomes than the direct learning model.

The experimental class that was treated with a cooperative learning model type Group Investigation made students more active because the steps in the learning process made students find the concepts in the Salt Hydrolysis material with a little guidance from the teacher, this is in accordance with the opinion of (Purwadi et al. 2013) namely the cooperative learning model Gl type, the group of students in conducting investigations has the smallest problem in building student appreciation abilities which makes students more active in the teaching and learning process.

The steps carried out by researchers in the experimental class are in accordance with (Joyce et al. 2003; Silaban, 2017), namely in the first step the researcher presents a problem regarding the material then organizes students into several groups, then plans learning procedures, assignments, and objectives of the topics that have been set in the previous step then directing students to learning activities that involve a wide variety of skills and activities (Lestari et al. 2020; Alfiahas et al. 2020; Ebiati et al. 2020). Strictly following the progress of each group and offering assistance if needed, at this stage students in each group are free to carry out investigations to find solutions given in the first step. Monitor and follow the progress of each group and offer assistance as needed and coordinate student presentations. Finally, evaluate each group's contribution to class work as a whole. It is because students tend to be more active so that the concepts that students get are more imprinted on them so that they can improve student learning outcomes.

The control class applies direct instruction learning which begins by explaining the subject matter to students and linking it to students' daily lives, students are asked to understand the material that has been delivered by providing the opportunity to ask questions if they do not understand. Finally given assignments that are relevant to the material that has been presented and give tests. In accordance with conventional learning students are more dependent on the teacher and the material that is reminded by students will not last long, this can be proven if the questions asked are slightly different from the example questions given, students cannot answer them, causing student learning outcomes in the control class to be low .

The results of the second hypothesis test, the effect of student adversity quotient (AQ) on chemistry mastery of salt hydrolysis material, it appears that $F_{\text {count }}$ is 17.394 with a significance value of 0.000 . Because the significance $<0.05$, Ho is rejected and 
$\mathrm{H} 1$ is accepted. This means that there is the influence of students' Adversity Quotient (AQ) on their mastery of chemical concepts in salt hydrolysis.

The learning outcomes among students who had the Adversity Quotient for the type of climbers were different from those of the students who had the Adversity Quotient for the campers type. Campers-type Adversity Quotient students find it easier to capture phenomena and respond to information provided by the teacher. The higher the Adversity Quotient the student has, the better student learning outcomes will be and vice versa. This is in line with (Budiada, 2013) that individuals who have high Adversity Quotient have a strong level of control over bad events. High control has far-reaching and positive implications and is very beneficial for performance and productivity. High Adversity Quotient teaches people to increase a sense of responsibility as a way to expand control, empowerment and motivation in taking action, so it can be concluded that the Adversity Quotient affects student learning outcomes.

The results of this study indicate that students who have the campers type of Adversity Quotient will produce low learning outcomes while students who have the climbers type of Adversity Quotient will produce high learning outcomes. This condition can be seen in the cooperative learning class Group Investigation type where the cooperative learning model Group Investigation type is suitable for students who have Adversity Quotient climbers type.

Student Adversity Quotient affects student learning outcomes. Students who had the Adversity Quotient for the climbers type were easier to develop their learning outcomes than students who had the campers-type Adversity Quotient. This is in accordance with the results of research (Budiada, 2013) which states that the learning outcomes of students who have high Adversity Quotient are better than students who have low $A Q$ and (Wismayana, 2007) states that the learning achievement of students who have a high Adversity Quotient is higher than students who have low Adversity Quotient and (Lubis, 2017) stated that students who have high Adversity Quotient have better physics learning outcomes than students who have low Adversity Quotient.

The third hypothesis test results, the interaction between the group investigation $\mathrm{GI}$ learning model and the adversity quotient on the mastery of chemical concepts in the salt hydrolysis material, it can be seen that the Fcount is 1.361 with a significance value of 0.264 . Because the significance $>0.05$, Ho is accepted and $\mathrm{H} 1$ is rejected. This means that there is no interaction between the group investigation ( $\mathrm{Gl}$ ) learning model and the adversity quotient (AQ) on the mastery of chemical concepts on salt hydrolysis.

Based on the results of this study, each variable, be it the independent variable, namely the $\mathrm{Gl}$ cooperative learning model and the moderator variable, namely the Adversity Quotient (AQ), each work in influencing the dependent variable (mastery of chemical concepts). This is due to the many factors that affect student learning 
outcomes or students' mastery of chemical concepts including internal factors and external factors. The graph of the interaction between the group investigation type cooperative learning model and the adversity quotient of students in influencing mastery of chemical concepts can be seen in Fig 3 .

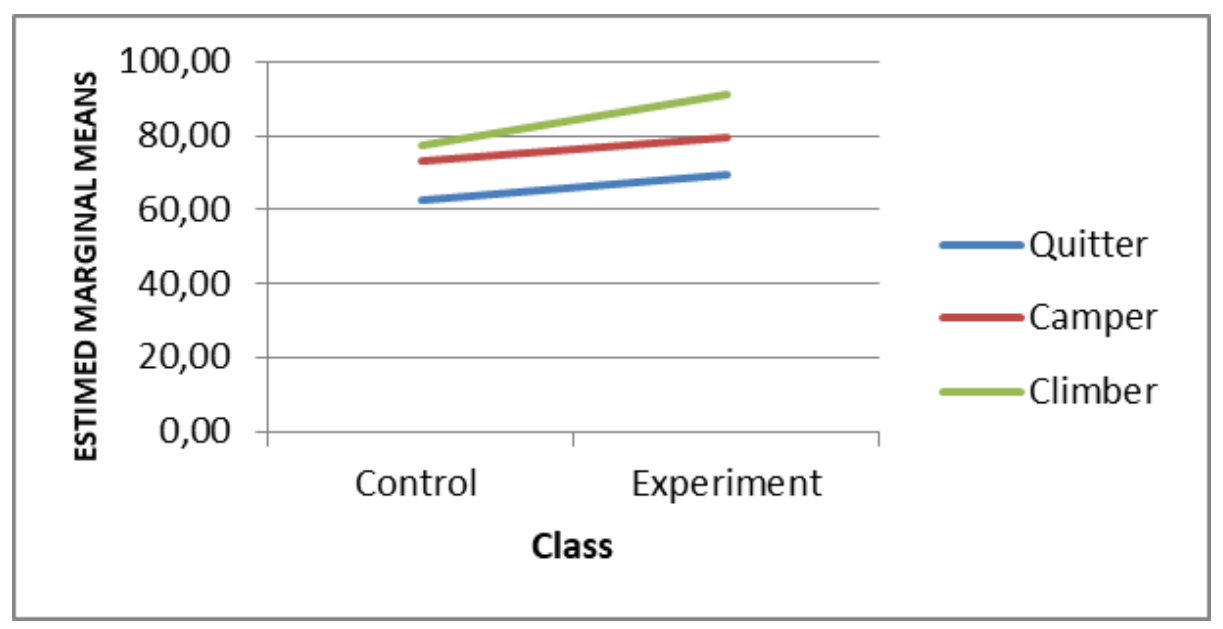

Fig 3. Graph of the interaction of the GI cooperative learning model and the student's Adversity Quotient (AQ)

Many factors can affect learning outcomes or mastery of chemical concepts besides the learning model and the Adversity Quotient. The factors that affect learning outcomes (concept mastery) according to Munatri et al. (2016) include internal factors and external factors. Internal factors include physiological factors and psychological factors. Physiological factors, in general, are physiological conditions, such as excellent health, not being tired and tired, not in a physical disability and so on. This can affect students in receiving subject matter. Psychological factors of each individual, in this case students basically have different psychological conditions, of course this also affects learning outcomes. Several psychological factors include intelligence (IQ), attention, interests, talents, motives, motivation, cognitive and reasoning power of students.

While external factors include environmental factors and instrumental factors. Environmental factors can influence learning outcomes. These environmental factors include the physical environment and the social environment. Natural environment such as temperature, humidity and others. Studying at midday in a room that lacks air circulation will be very influential and will be very different from learning in the morning where the conditions are still fresh and with enough room to breathe freely. Instrumental factors. Instrumental factors are factors whose existence and use are designed in accordance with the expected learning outcomes. These factors are expected to function as a means of achieving planned learning goals. These instrumental factors are in the form of curriculum, facilities and teachers. 


\section{Conclusion}

Based on the results of research and discussion it can be concluded as follows: 1) there is an effect of the Group Investigation type cooperative learning model on the mastery of chemical concepts in the salt hydrolysis material (2) there is an effect of the students' adversity quotient on the mastery of chemical concepts in the salt hydrolysis material (3) there is no interaction between the Group Investigation Type Cooperative Learning Model with Adversity Quotient of students on mastery of chemical concepts in salt hydrolysis material.

\section{Acknowledgment}

We would like to express our gratitude to all parties who have given contribution on the research especially to the master, teacher and students of SMA 10 Batanghari as well as our colleques.

\section{References}

Alfiahas, R., Asrial, A., \& Muhammad, D. The effect of portfolio-based learning models and self-regulated learning on student's creative thinking skills on acid and base materials. Jurnal Pendidikan Kimia, 12(2), 88-94, DOI: 10.24114/jpkim.v12i2.19406.

Andi \& Handayani (2015). Pengaruh model pembelajaran Gl dengan scaffolding terhadap penguasaan konsep fisika. Jurnal Pemikiran Penelitian Pendidikan dan Sains, 3(6), 159-169, DOI: 10.31102/wacanadidaktika.3.2.

Anitah, S. (2007). Strategi pembelajaran. Jakarta: Universitas Terbuka.

Budiada, I. W. (2011). Pengaruh penerapan model pembelajaran inkuiri terbimbing berbasis asesmen portofolio terhadap hasil belajar kimia siswa kelas $\mathrm{X}$ ditinjau dari adversity quotient. Jurnal Penelitian dan Evaluasi Pendidikan Indonesia, 1(2), 1-16.

Ebiati, E., Asrial, A., \& Effendi-Hasibuan, M. H. Sensitivity of two-tier and three-tier tests in detecting student's misconceptions of chemical bonding. Jurnal Pendidikan Kimia, 12(2), 79-87, DOI: 10.24114/jpkim.v12i2.19405.

Ekayanti, N. W., Puspitawati, D. A., \& Surata, S. P. K. (2011). Upaya peningkatan keterampilan sosial dalam ekoliterasi ketahanan hayati melalui pembelajaran kooperatif tipe kelompok investigasi pada mahasiswa pendidikan biologi semester III tahun akademik 2008/2009. Jurnal Santiaji Pendidikan (JSP), 1(1), 14-21, DOI:10.36733/jsp.v111.457

Fauziah, M., Marmoah, S., Murwaningsih, T., \& Saddhono, K. (2020). The effect of thinking actively in a social context and creative problem-solving learning models on divergentthinking skills viewed from adversity quotient. European Journal of Educational Research, 9(2), 537-568, DOI: 10.12973/eu-jer.9.2.53

Hartoto, T. (2016). Model pembelajaran kooperatif tipe group investigation (GI) Meningkatkan aktivitas dan hasil belajar sejarah. HISTORIA, 4(2), 131, DOl:10.24127/hj.v4i2.553

Joyce, B., Weil, M., and Calhoun, E. (2003). Models of Teaching. Centers for Teaching and Technology - Book Library. 96. 
Lestari, D. I., Effendi-Hasibuan, M. H., \& Muhammad, D. (2020). The effect of the flipped classroom approach and self-efficacy on a guided inquiry on students' creative thinking skills. Jurnal Pendidikan Kimia, 12(2), 95-105, DOI: 10.24114/jpkim.v12i2.19435.

Lubis, R. H. (2017). Pengaruh model pembelajaran kooperatif tipe group investigation terhadap hasil belajar fisika siswa ditinjau dari adversity quotient siswa. Jurnal Pendidikan Fisika, 6(1), 44-49, DOI:10.22611/jpf.v6il.6344

Munatri, S., Suyatna, A., \& Yulianti, D. (2016). Penerapan model pembelajaran inkuiri terbimbing untuk meningkatkan hasil belajar. Jurnal Teknologi Informasi Komunikasi Pendidikan (Old), 4(1).

Purwadi, Suwandi, S., Budiyono, Slamet. St. Y. (2013). The effect of the contextual, the problem-based, and the group investigation learning models on the short story appreciation ability viewed from the verbal linguistic intelligences. Journal of Education and Practice, 4(12), 90-102.

Rokhayati, N. (2010). Peningkatan penguasaan konsep matematika melalui model pembelajaran guided discovery-inquiry pada siswa kelas VII SMP N 1 Sleman. Skripsi: Universitas Negeri Yogyakarta.

Silaban, S. (2017). Dasar-dasar pendidikan matematika dan ilmu pengetahuan alam. Medan: Harapan Cerdas Publisher.

Stoltz, P. G. (2000). Adversity quotient: Mengubah hambatan menjadi peluang. Jakarta: Gramedia Widiasarana Indonesia.

Wismayana, N. P. (2007). Pengaruh model belajar berbasis masalah dan adversity quotient siswa terhadap prestasi belajar matematika dan konsep diri siswa SMA Negeri 4 Singaraja. JIPP, 774-787. 